\title{
UGDYMO POVEIKIS PRIEŠMOKYKLINIO AMŽIAUS VAIKŲ RANKŲ KOORDINACIJOS REZULTATŲ KAITAI
}

\author{
Zina Birontienè \\ Klaipédos universitetas, Klaipéda, Lietuva
}

\begin{abstract}
Zina Birontienė. Socialinių mokslų (edukologijos) daktarė. Klaipėdos universiteto Kūno kultūros katedros docentè. Mokslinių tyrimų kryptis - priešmokyklinio (5-7 metu) amžiaus vaikų fizinis brandinimas mokyklai, sveikatos saugojimo kompetencijos ugdymas.
\end{abstract}

\section{SANTRAUKA}

Tyrimo tikslas - ištirti 5-7 metu vaiku ranku koordinacijos rezultatu kaitq optimizuojant fizinio brandinimo mokyklai procesa.

Naudoti šie tyrimo metodai: ugdomasis eksperimentas, testavimas, pedagoginis stebèjimas ir matematine statistinè analizè. Ugdomasis eksperimentas vyko 20 ménesiu. Buvo tiriama 120 vaiku iš Klaipédos miesto vaiku lopšeliu-darželiu. Eksperimentinèje (E) grupèje vaikai buvo ugdomi pagal mūsu sukurta fizinio brandinimo mokyklai programq. Pirštu, plaštakos ir visos rankos lavinimo pratimai, žaidimai su kamuoliais buvo ịtraukti i rytinès mankštos ir kūno kultūros pratybu pratimu kompleksus. Kontrolinè (K) grupé dirbo pagal Lietuvos Respublikos Švietimo ministerijos patvirtinta ,, Vérinèlio “ programa. Atlikti trys tyrimai. Vaikai turèjo atlikti penkias užduotis su teniso kamuoliu ir tris pirštu lietimo užduotis, vertinančias akiu, ranku judesiu koordinacija ir ranku, plaštaku, pirštu judesiu tikslumq.

Pirmo tyrimo metu E ir K grupès tiriamuju ranku koordinacijos rezultatai buvo labai panašūs. Per aštuonis mènesius trukusi kryptinga ir tikslinga ranku koordinacijos lavinima tarp pirmo ir antro tyrimo nustatyti E grupés mergaičiu statistiškai patikimai $(p<0,05-0,001)$ ryškesni septyniu, E grupès berniuku—aštuoniu užduočiu $(p<0,05-0,001)$ rezultatu poslinkiai. Tuo tarpu K grupès mergaičiu - vienos užduoties pagerèjo $(p<0,01)$, o berniuku—vienos užduoties pagerèjo $(p<0,05)$, kitos — pablogèjo $(p<0,05)$. Antro tyrimo septyniu užduočiu $(p<0,01-0,001)$ rezultatu aritmetiniai vidurkiai E mergaičiu ir berniuku grupèse buvo statistiškai patikimai geresni nei K grupès mergaičiu ir berniuku. Per likusius dvylika mènesiu (tarp antro ir trečio tyrimo) visu grupiu vaiku ranku koordinacija pagerèjo, tačiau E grupès mergaičiu vidutiniai rezultatai statistiškai patikimai $(p<0,01-0,001)$ išaugo penkiu, o berniuku— —eturiu užduoči $(p<0,05-0,001)$, K mergaičì grupejje — keturiu $(p<0,05)$, berniuku — penkiu užduočiu $(p<0,05-0,001)$. E grupès vaikai kur kas gerian gaudè kamuoliuka, taikliau metè i taikini, koordinavo pirštu galiuku lytèjima užmerktomis ir atmerktomis akimis. Trečio tyrimo metu E grupès mergaitès buvo statistiškai patikimai pranašesnès atlikdamos septynias $(p<0,01-0,001)$, o berniukai šešias $(p<0,01-0,001)$ užduotis, lyginat su K grupe. Visu tyrimu metu nustatyta didele individualiu ranku koordinacijos rezultatu sklaida.

Mūsu tyrimo rezultatai panašüs kaip ir kitu vaiku koordinacija tyrusiu mokslininku (Durandt, 1985; Adaškevičienè, 1993; Михайлова, 1993; Лагутин, Амаръян, 2002; Dankert et al., 2003; Sugden, Chambers, 2003). Jie patvirtina teiginius, kad rengiant vaikus mokyklai tikslinga naudoti gana sudetingus ranku koordinacijos pratimus, kuriems atlikti bütina sqmoninga jutimu integracija ir suvokimo kontrolè. Ugdomojo eksperimento rezultatai rodo, kad sistemingai ir tikslingai atliekami ranku, riešo ir pirštu lavinimo žaidimu pratimai, žaidimai su kamuoliu gerina ranku koordinacijos kiekybinius ir kokybinius rodiklius.

Raktažodžiai: ranku koordinacija, Bruininks-Oseretsky motoriniu igūdžiu testai, 5-7 metu vaiku fizinio brandinimo mokyklai programa.

\section{IVADAS}

$\mathrm{V}$ aikas brandus mokyklai, kai yra igijęs pažinimo, sveikatos saugojimo, meninę, komunikavimo ir socialinę kompetenciją. Šiandieninè samprata teigia, kad priešmokyklinis ugdymas - tai ne siauras dalykinis vaiko mokymas skaityti, rašyti, skaičiuoti, o visu jo fiziniu ir psichiniu galiu plètotè bei puoselèjimas, pozityvios socialinès ir emocinès patirties igijimas, pažinimo motyvacijos žadinimas, kūrybiškumo skatinimas.
Pradejjęs lankyti mokyklą vaikas jau pirmoje klaseje turi išmokti aiškiai, estetiškai ir taisyklingai rašyti, sklandžiai skaityti, ugdytis meninius ir technologinius gebėjimus (piešti, konstruoti, šokti, vaidinti ir pan.). Visa ši ugdomoji veikla reikalauja gerai išlavintų pirštų ir visos rankos judesių, pirštu ir riešo judesiu kontrolès akimis. Rašymas ir skaitymas yra sudètingos struktūros kompleksiniai mokejjimai, apimantys artikuliacijos ir klausos analizès mechanizmus, regimają atminti 
ir regimają kontrolę, akių ir rankos judesių koordinaciją, motorinę kontrolę, percepcini reguliavima, garsinę raidès analizę ir pan. (Søvik., Maeland, 1987). Pirštu motorikos automatizavimas negali būto izoliuotas vyksmas (Bruininks et al., 1974). Vadinasi, rašant, skaitant būtina vizualinè-percepcinè ir rankos motorinè integracija. Todèl rengiant vaikus mokyklai reikia tinkamai išlavinti rankos judesius, sensorinių sistemų integraciją krypties suvokimą ir skyrima.

Rašymo procesas yra sudètingas dar ir dèl 5-7 metų vaikų fizinio vystymosi ypatumų. Šio amžiaus vaikai sunkiai išlaiko statinę sẻdejjimo pozą. Nugaros tiesiamieji raumenys dar yra silpni, todèl vaikai negali ilgai taisyklingai sèdèti. Jie kūprinasi, persikreipia ir sukinejasi. 5-7 metu vaikų smulkieji plaštakos raumenys silpnai išlavinti, nepasibaigęs riešo ir pirštų sukaulejjimas, netobulas nervinis judesių reguliavimas (Griniené ir kt., 1990). Be to, nesuformuoti daugelio vaiku erdvès suvokimo ir regimosios atminties, akių ir rankos judesiu koordinacijos mechanizmai, ir tai sudaro papildomų sunkumų (Kuhtz-Buschbeck et al., 1998; Inui, Katsura, 2002).

Vaikų rankų judesiai lavejja buitinèje veikloje. Pirštų judesius lavina piešimas, karpymas, konstravimas, lipdymas, stalo žaidimai su smulkiomis detalèmis. Moksliniais tyrimais įrodyta, kad smulkiają motoriką galima tinkamai išlavinti specialia fizine veikla (Kephard, 1971; Тулва, 1976; Adaškevičienè, 1993; Strazdienè, 2001), tačiau nėra žinoma, kaip rankų koordinacijos lavejjimą veikia fizinis ugdymas, rengiant vaikus mokyklai.

Hipotezè: jei 5-7 metu vaikus rengdami mokyklai ugdymo procese naudosime pirštų ir visos rankos lavinimo pratimus ir žaidimus, kuriems būtina sąmoninga, atidi kontrolè akimis, turètų gereti rankų judesių koordinacija.

Tyrimo objektas $-5-7$ metų vaikų rankų koordinacijos rezultatų kaita.

Tyrimo tikslas - ištirti $5-7$ metu vaiku rankų koordinacijos rezultatų kaitą optimizuojant fizinio brandinimo mokyklai procesą.

\section{TYRIMO METODIKA}

Taikyti šie tyrimo metodai: ugdomasis eksperimentas, testavimas, pedagoginis stebejjimas, matematinè statistinè analizè.

Rankų koordinacijos testavimas. Testavimo metu vaikai turèjo atlikti aštuonias užduotis: keturias teniso kamuoliuko metimo ir gaudymo, vieną mètymo į taikini ir tris lietimo pirštu galais (užmerktomis ar atmerktomis akimis) (žr. lent.). Užduočiu su kamuoliuku atlikimo laikas nebuvo ribojamas. Vengiant mokymo efekto, prieš kiekvieną užduotị buvo leidžiama tris kartus pabandyti ir isitikinti, ar vaikas tikrai gerai suprato užduotic. Po trijų bandymų buvo atliekami penki įskaitiniai kamuoliuko gaudymai ar metimai $\mathfrak{i}$ taikini. Iskaitomi tik sugauti ar pataikyti i taikini kamuoliukai. Pirštu lietimo užduotis testuotojas iš pradžiu paaiškindavo ir parodydavo, leisdamas vaikui užduoti bandyti atlikti kartu. Šioms užduotims atlikti buvo skiriama 90 sekundžių. Jei vaikas, atlikdamas lietimo pirštuc galais užduotis, suklysdavo pradejjus skaičiuoti laiką, testuotojas klaidas aiškindavo žodžiu, bet užduoties atlikimo nenutraukdavo. Užduotis būdavo iskaitoma tik tuo atveju, jeigu per 90 sekundžiu vaikas, supratęs savo klaidas, spėdavo taisyklingai atlikti nurodytą skaičių nenutrūkstamų judesių sekų. Be to, užduotys (nosies lietimo rodomaisiais pirštais ir pirštų galiukų lietimo), kurias reikejjo atlikti užsimerkus buvo neiskaitomos, jei vaikas atsimerkdavo nebaigęs užduoties.

Pedagoginis stebėjimas. Norèdami kokybiškai ivertinti vaiku ranku koordinacinius gebejjimus, visu testavimų metu stebėjome vaikų judesius. Jie buvo aprašomi individualioje vaiko testavimo rezultatų kortelëje, pastabų lape. Visų testavimų metu buvo aprašoma vaikų rankų, plaštakos ir pirštų atliekamu judesių kontrolè rega, erdvès, krypties ir judesių amplitudès suvokimas, judesių tikslumas, tolygumas, operatyvumas ir racionalumas. Stebejimas taip pat leido daryti prielaidas apie sensomotorinę (lytėjimo, regos, raumenu itempimo) integraciją ir dèmesio koncentraciją.

Matematinė statistika. Apskaičiuotas aritmetinis vidurkis, standartinis nuokrypis ir aritmetinio vidurkio paklaida. Skirtumo tarp aritmetinių vidurkių statistinis reikšmingumas buvo nustatomas pagal Stjudento $t$ (Student $t$ ) kriteriju. Aritmetiniu vidurkių skirtumo reikšmingumo lygmuo buvo laikomas svarbiu, kai paklaida mažesnè nei 5\% (p < $0,05)$. Skaičiavimai atlikti skaičiuokle $M S E X C E L$ 2000 ir kompiuterine programa SPSS 13.0.

Tyrimo organizavimas. Keturiuose Klaipèdos miesto vaikų lopšeliuose-darželiuose atliktas ugdomasis eksperimentas truko 20 mènesių. Buvo tiriama 120 vaikų. Eksperimentinę (E) grupę sudarè 62 , kontrolinę $(\mathrm{K})-58$ vaikai. E grupès vaikai buvo ugdomi pagal mūsų parengtą $5-7$ metų vaiku fizinio brandinimo mokyklai programą, kurios viena iš sudedamujuc dalių - smulkiosios motorikos ir koordinacijos ugdymas. Ją sudarè: ịvairūs pirštu lavinimo pratimai ir žaidimai; pratimai su 
Lentelè. Eksperimentinès ir kontrolinės grupès vaikų rankų koordinacijos užduočių rezultatai $(\bar{x} \pm \mathbf{S D}$; \% ir n)

\begin{tabular}{|c|c|c|c|c|c|c|c|c|c|}
\hline \multirow{3}{*}{$\begin{array}{l}\mathbf{T} \\
\mathbf{y} \\
\mathbf{r} \\
\mathbf{i} \\
\mathbf{m} \\
\mathbf{a} \\
\mathbf{i}\end{array}$} & \multirow[b]{3}{*}{ Grupè } & \multicolumn{8}{|c|}{ Rankų koordinacijos užduotys } \\
\hline & & \multicolumn{2}{|c|}{$\begin{array}{l}\text { Kamuoliuko metimas i } \\
\text { grindis ir gaudymas }\end{array}$} & \multicolumn{2}{|c|}{$\begin{array}{l}\text { Metamo kamuoliuko } \\
\text { gaudymas }\end{array}$} & \multirow{2}{*}{$\begin{array}{c}\text { Kamuoliuko } \\
\text { metimas } \\
\text { i taikini } \\
\text { dominuojan- } \\
\text { čia ranka, } \\
\text { kartai }\end{array}$} & \multirow{2}{*}{$\begin{array}{c}\text { Nosies } \\
\text { lietimas } \\
\text { rodomaisiais } \\
\text { pirštais } \\
\text { užmerktomis } \\
\text { akimis, } \\
\text { iskaityta }\end{array}$} & \multirow{2}{*}{$\begin{array}{c}\text { Pirštų } \\
\text { galiukų } \\
\text { lietimas } \\
\text { nykščiu } \\
\text { užmerktomis } \\
\text { akimis, } \\
\text { iskaityta }\end{array}$} & \multirow{2}{*}{$\begin{array}{c}\text { Nykščių ir } \\
\text { rodomŭjų } \\
\text { pirštų } \\
\text { sukinèjimas, } \\
\text { iskaityta }\end{array}$} \\
\hline & & $\begin{array}{c}\text { Abiem } \\
\text { rankom, } \\
\text { kartai }\end{array}$ & $\begin{array}{c}\text { Dominuo- } \\
\text { jančia } \\
\text { ranka, } \\
\text { kartai }\end{array}$ & $\begin{array}{c}\text { Abiem } \\
\text { rankom, } \\
\text { kartai }\end{array}$ & $\begin{array}{c}\text { Dominuo- } \\
\text { jančia } \\
\text { ranka, } \\
\text { kartai }\end{array}$ & & & & \\
\hline \multirow{4}{*}{ I } & E gr. mergaitès & $\begin{array}{c}3,03 \\
\pm 0,28\end{array}$ & $\begin{array}{c}1,94 \\
\pm 0,28\end{array}$ & $\begin{array}{l}1,70 \\
\pm 0,27\end{array}$ & $\begin{array}{c}0,15 \\
\pm 0,08\end{array}$ & $\begin{array}{c}1,48 \\
\pm 0,20\end{array}$ & $\begin{array}{l}75,76 \\
25\end{array}$ & $\begin{array}{c}51,52 \\
17\end{array}$ & $\begin{array}{c}63,64 \\
21\end{array}$ \\
\hline & K gr. mergaitès & $\begin{array}{c}2,76 \\
\pm 0,34\end{array}$ & $\begin{array}{c}1,59 \\
\pm 0,33 \\
\end{array}$ & $\begin{array}{c}1,21 \\
\pm 0,22 \\
\end{array}$ & $\begin{array}{c}0,14 \\
\pm 0,08\end{array}$ & $\begin{array}{c}1,28 \\
\pm 0,24\end{array}$ & $\begin{array}{c}82,76 \\
24\end{array}$ & $\begin{array}{c}37,93 \\
11\end{array}$ & $\begin{array}{c}65,52 \\
19\end{array}$ \\
\hline & E gr. berniukai & $\begin{array}{l}2,96 \\
0,40\end{array}$ & $\begin{array}{c}1,60 \\
\pm 0,34\end{array}$ & $\begin{array}{c}1,56 \\
\pm 0,36\end{array}$ & $\begin{array}{c}0,36 \\
\pm 0,18\end{array}$ & $\begin{array}{c}1,52 \\
\pm 0,22\end{array}$ & $\begin{array}{c}60,00 \\
15\end{array}$ & $\begin{array}{c}40,00 \\
10\end{array}$ & $\begin{array}{c}48,00 \\
12\end{array}$ \\
\hline & K gr. berniukai & $\begin{array}{c}2,79 \\
\pm 0,28\end{array}$ & $\begin{array}{c}1,79 \\
\pm 0,30\end{array}$ & $\begin{array}{c}1,52 \\
\pm 0,29\end{array}$ & $\begin{array}{c}0,14 \\
\pm 0,11\end{array}$ & $\begin{array}{c}1,97 \\
\pm 0,26\end{array}$ & $\begin{array}{c}62,07 \\
18\end{array}$ & $\begin{array}{c}41,38 \\
12\end{array}$ & $\begin{array}{c}58,62 \\
17\end{array}$ \\
\hline \multirow{4}{*}{ II } & E gr. mergaitès & $\begin{array}{c}4,44 * * * \\
\pm 0,13\end{array}$ & $\begin{array}{c}4,03 * * * \\
\pm 0,19\end{array}$ & $\begin{array}{c}3,66 * * * \\
\pm 0,20\end{array}$ & $\begin{array}{l}0,53^{*} \\
\pm 0,22\end{array}$ & $\begin{array}{c}2,25 * * * \\
\pm 0,21\end{array}$ & $\begin{array}{c}96,88^{*} \\
31\end{array}$ & $\begin{array}{c}84,38 \\
27\end{array}$ & $\begin{array}{c}96,88 * * \\
31\end{array}$ \\
\hline & K gr. mergaitès & $\begin{array}{c}2,97 \\
\pm 0,26 \\
\end{array}$ & $\begin{array}{c}1,38 \\
\pm 0,23 \\
\end{array}$ & $\begin{array}{c}1,14 \\
\pm 0,27 \\
\end{array}$ & $\begin{array}{c}0,03 \\
\pm 0,03\end{array}$ & $\begin{array}{c}1,07 \\
\pm 0,19\end{array}$ & $\begin{array}{c}75,86 \\
22\end{array}$ & $\begin{array}{c}72,41 \\
21\end{array}$ & $\begin{array}{c}68,97 \\
20\end{array}$ \\
\hline & E gr. berniukai & $\begin{array}{l}4,46 * * \\
\pm 0,22\end{array}$ & $\begin{array}{l}3,58 * * \\
\pm 0,31 \\
\end{array}$ & $\begin{array}{l}2,75^{*} \\
\pm 0,38 \\
\end{array}$ & $\begin{array}{c}1,42 \\
\pm 0,33 \\
\end{array}$ & $\begin{array}{c}2,67 * * * \\
\pm 0,24\end{array}$ & $\begin{array}{c}91,67^{*} \\
22 \\
\end{array}$ & $\begin{array}{c}83,33 * \\
20 \\
\end{array}$ & $\begin{array}{c}87,50 * * * \\
21\end{array}$ \\
\hline & K gr. berniukai & $\begin{array}{c}3,24 \\
\pm 0,30\end{array}$ & $\begin{array}{c}2,21 \\
\pm 0,27\end{array}$ & $\begin{array}{c}1,69 \\
\pm 0,30\end{array}$ & $\begin{array}{c}0,76 \\
\pm 0,21\end{array}$ & $\begin{array}{c}1,31 \\
\pm 0,24\end{array}$ & $\begin{array}{c}68,97 \\
20\end{array}$ & $\begin{array}{c}51,72 \\
15\end{array}$ & $\begin{array}{c}31,03 \\
9\end{array}$ \\
\hline \multirow{4}{*}{ III } & E gr. mergaitès & $\begin{array}{c}4,93 * * * \\
\pm 0,05\end{array}$ & $\begin{array}{c}4,59 * * * \\
\pm 0,12\end{array}$ & $\begin{array}{c}4,17 * * * \\
\pm 0,13\end{array}$ & $\begin{array}{c}2.66 * * * \\
\pm 0,21\end{array}$ & $\begin{array}{c}2,72 * * * \\
\pm 0,16\end{array}$ & $\begin{array}{c}100,00 \\
29 \\
\end{array}$ & $\begin{array}{c}100,0^{* *} \\
29\end{array}$ & $\begin{array}{c}100,0^{* *} \\
29\end{array}$ \\
\hline & K gr. mergaitès & $\begin{array}{c}3,81 \\
\pm 0,28\end{array}$ & $\begin{array}{c}2,22 \\
\pm 0,28 \\
\end{array}$ & $\begin{array}{c}1,37 \\
\pm 0,28 \\
\end{array}$ & $\begin{array}{c}0,33 \\
\pm 0,12 \\
\end{array}$ & $\begin{array}{c}1,00 \\
\pm 0,17 \\
\end{array}$ & $\begin{array}{c}96,30 \\
26\end{array}$ & $\begin{array}{c}77,78 \\
21 \\
\end{array}$ & $\begin{array}{c}74,07 \\
20 \\
\end{array}$ \\
\hline & E gr. berniukai & $\begin{array}{c}4,87 * * * \\
\pm 0,07\end{array}$ & $\begin{array}{c}4,74 * * * \\
\pm 0,11\end{array}$ & $\begin{array}{l}3,61 * * \\
\pm 0,16\end{array}$ & $\begin{array}{c}2,74 * * * \\
\pm 0,23\end{array}$ & $\begin{array}{l}2,70 * * \\
\pm 0,19\end{array}$ & $\begin{array}{c}100,00 \\
23 \\
\end{array}$ & $\begin{array}{c}95,65 \\
22 \\
\end{array}$ & $\begin{array}{c}100,0^{* *} \\
23\end{array}$ \\
\hline & K gr. berniukai & $\begin{array}{c}4,33 \\
\pm 0,16\end{array}$ & $\begin{array}{c}3,74 \\
\pm 0,24\end{array}$ & $\begin{array}{c}2,70 \\
\pm 0,31\end{array}$ & $\begin{array}{c}1,00 \\
\pm 0,26\end{array}$ & $\begin{array}{c}1,89 \\
\pm 0,20\end{array}$ & $\begin{array}{c}100,00 \\
27\end{array}$ & $\begin{array}{c}96,30 \\
26\end{array}$ & $\begin{array}{c}66,67 \\
18\end{array}$ \\
\hline \multirow{4}{*}{ 夢 } & E gr. mergaitès & $* * *$ & $* * *$ & $* * *$ & & $* *$ & $*$ & $* *$ & $* * *$ \\
\hline & K gr. mergaitès & & & & & & & $* *$ & \\
\hline & E gr. berniukai & $* *$ & $* * *$ & $*$ & $*$ & $* * *$ & $* *$ & $* *$ & $* *$ \\
\hline & K gr. berniukai & & & & $*$ & & & & $*$ \\
\hline \multirow{4}{*}{ 兽 } & E gr. mergaitès & $* * *$ & $* * *$ & $*$ & $* * *$ & & & $*$ & \\
\hline & K gr. mergaitès & $*$ & $*$ & & $*$ & & $*$ & & \\
\hline & E gr. berniukai & & $* * *$ & $*$ & $* *$ & & & $*$ & \\
\hline & K gr. berniukai & $* * *$ & $* * *$ & $*$ & & & $* *$ & & $* *$ \\
\hline
\end{tabular}

Pastaba. $*-\mathrm{p}<0,05 ; * *-\mathrm{p}<0,01 ; * *-\mathrm{p}<0,001$. Taip pat reiškia rezultatų skirtumo patikimumo lygmenis tarp $\mathrm{E}$ ir $\mathrm{K}$ grupių.

lauko teniso kamuoliukais; pratimai, lavinantys krypties suvokimą ir orientaciją erdvèje. E grupès žaidimu ir sporto kampeliai buvo papildyti naujais dẻlionių žaidimais, smulkiais konstruktoriais, smulkia gamtine medžiaga, mažais ir dideliais kamuoliais, karpymo priemonėmis. K grupè dirbo pagal Lietuvos Respublikos Švietimo ministerijos parvirtintą „Vèrinèlio“ programą. Atlikti trys testavimai: prieš eksperimenta, po aštuonių mènesiu ir jo pabaigoje.

\section{REZULTATAI}

Pagal Bruininks-Oseretsky motoriniu igūdžių testų (Bruininks, 2000) struktūrą rankų koordinacija apima tiek smulkiaja, tiek bendrają motoriką. Aštuoniomis rankų koordinacijos užduotimis buvo tiriama akių, ranku judesių koordinacija ir ranku, plaštakų, pirštu judesių tikslumas.

Pirmo tyrimo metu E ir K grupių vaikų visu rankos koordinacijos užduočių rezultatai buvo pa- 
1 pav. Eksperimentinès ir kontrolinès grupès vaikų kamuoliuko metimo ị taikinį rezultatų kaita
Pastaba. ** - p $<0,01 ; * * *-\mathrm{p}<$ 0,001 ; skirtumo reikšmingumo lygmuo, lyginant $\mathrm{E}$ ir $\mathrm{K}$ grupiu mergaičiu bei $\mathrm{E}$ ir $\mathrm{K}$ grupių berniukų antro ir trečio tyrimo rezultatu aritmetinius vidurkius.

2 pav. Eksperimentinès ir kontrolinès grupès vaikų nykščių bei rodomųjų pirštų sukinèjimo rezultatų kaita
Pastaba. $* *-\mathrm{p}<0,01 ; * * *-\mathrm{p}<$ 0,001 ; skirtumo reikšmingumo lygmuo, lyginant $\mathrm{E}$ ir $\mathrm{K}$ grupių mergaičių bei $\mathrm{E}$ ir $\mathrm{K}$ grupių berniukų antro ir trečio tyrimo rezultatu aritmetinius vidurkius.
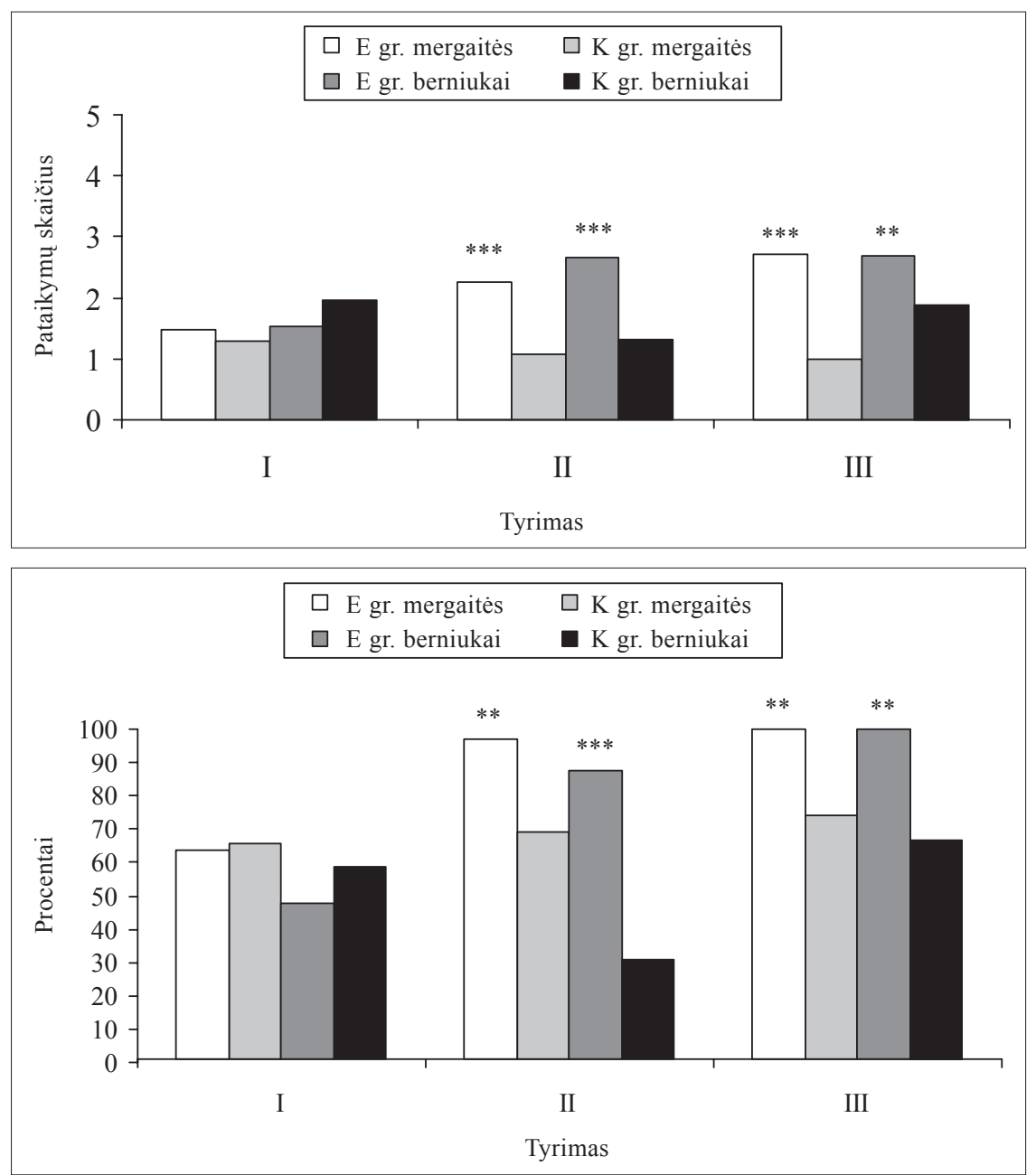

našūs. Rezultatų aritmetiniai vidurkiai statistiškai nepatikimi (žr. lent.).

Per aštuonis mėnesius trukusi sistemingą ir tikslingą rankų koordinacijos lavinimą tarp pirmo ir antro tyrimo nustatyti $\mathrm{E}$ grupès mergaičiu statistiškai patikimai $(\mathrm{p}<0,05-0,001)$ ryškesni septynių, E grupès berniukų - aštuonių užduočių $(\mathrm{p}<0,05-0,001)$ rezultatu poslinkiai. Tuo tarpu $\mathrm{K}$ grupès mergaičiu — vienos užduoties pagerejo $(\mathrm{p}<0,01)$, berniuku — vienos užduoties pagerèjo $(\mathrm{p}<0,05)$, kitos - pablogèjo $(\mathrm{p}<0,05)$. Lyginant $\mathrm{E}$ ir $\mathrm{K}$ grupių rankų koordinacijos užduočiu rezultatus antro tyrimo metu matyti, kad E grupès mergaičių ir berniukų septynių (iš aštuonių) užduočių rezultatai yra statistiškai patikimai $(\mathrm{p}<$ $0,05-0,001)$ geresni negu $\mathrm{K}$ grupès mergaičiu ir berniuku.

Tarp antro ir trečio tyrimo visų grupių vaikų rankų koordinacija pagerèjo. E grupès mergaičių vidutiniai rezultatai statistiškai patikimai $(\mathrm{p}<0,01-$ $0,001)$ išaugo penkių, o berniuku - keturių užduočiu $(\mathrm{p}<0,05-0,001)$. K mergaičiu grupejje - keturių ( $p<0,05)$, berniuku — penkių užduočių ( $p<$ $0,05-0,001)$. Visgi trečio tyrimo metu E grupès vaikai kur kas geriau gaude kamuoliuką, taikliau mete i taikini, atlikdami lietimo pirštu galais užduotis geriau koordinavo judesius užmerktomis ir atmerktomis akimis. Iš lentelès matyti, kad E grupès mergaitès buvo statistiškai patikimai pranašesnès atlikdamos septynias $(\mathrm{p}<0,01-0,001)$, berniukai — šešias $(p<0,01-0,001)$ užduotis, lyginat su $\mathrm{K}$ grupès rezultatais. Didelè individualiu rankų koordinacijos rodiklių sklaida.

Kamuoliuko gaudymo abiem rankom rezultatai visose grupèse yra geresni negu viena ranka. Be to, penkerių-septynerių metų vaikams mesti kamuoliuka i grindis ir gaudyti lengviau, negu gaudyti kamuoliuką, testuotojo metamą iš trijų metru atstumo.

Testavimo rezultatai ir pedagoginis stebejjimas taip pat leidžia teigti, kad iš visų užduočių su kamuoliuku vaikams sunkiausia buvo kamuoliuko metimo į taikini užduotis. Pirmo tyrimo metu penkiamečių E ir K grupių mergaičių ir berniukų pataikymo i̇ taikinį rezultatų vidurkiai buvo ypač maži (1 pav.). E grupès mergaitès iš penkių metimu pataikè tik $1,48 \pm 0,20$, berniukai $-1,52$ $\pm 0,22, \mathrm{~K}$ grupès vaikai atitinkamai $1,28 \pm 0,24$ 
ir 1,97 $\pm 0,26$ karto. Antro tyrimo metu E grupès vaikų rezultatų vidurkiai buvo statistiškai patikimai geresni $(\mathrm{p}<0,01-0,001)$ už $\mathrm{K}$ grupès rezultatų vidurkius. E grupès mergaitès vidutiniškai pataikè 2,25 $\pm 0,21, \mathrm{~K}$ grupès - tik $1,07 \pm$ 0,19 , berniukai atitinkamai $2,67 \pm 0,24$ ir $1,31 \pm$ 0,24 karto. Trečio tyrimo rezultatai, lyginant su antro, pagerèjo labai nedaug, tačiau E grupès vaiku pataikymo vidurkiai, lyginat su $\mathrm{K}$ grupès, išliko statistiškai reikšmingi $(\mathrm{p}<0,01-0,001)$. E grupès mergaitès pataikè 2,72 $\pm 0,16$, berniukai $-2,70 \pm 0,19, \mathrm{~K}$ grupès berniukai $-1,87 \pm$ 0,20 karto, $\mathrm{K}$ grupès mergaičiu pataikymo vidurkis labai nedaug pablogejo. Jos pataikè tik 1,00土 0,17 karto.

Iš trijų pirštų galų lietimo užduočių sudètingiausia erdvinès koordinacijos požiūriu buvo nykščių ir rodomujų pirštų sukinèjimo užduotis. Pirmo tyrimo metu atskirose grupèse šią užduoti taisyklingai gebejo atlikti nuo 48,00 iki 65,52\% vaiku ( 2 pav.). Per antrą tyrimą vidutiniai rezultatai statistiškai reikšmingai pagerejo tik E mergaičiu ir berniuku grupèje, o K berniukų net pablogejjo. Trečio tyrimo metu šią užduoti taisyklingai gebèjo atlikti visi $\mathrm{E}$ grupès vaikai, o $\mathrm{K}$ grupèje - 74,07\% mergaičiu ir $64,67 \%$ berniuku.

\section{REZULTATUQ APTARIMAS}

Pirmą kartą tirta Lietuvos ikimokyklinio amžiaus vaiku pirštų, riešo ir visos rankos judesių koordinacija testavimu naudojant Bruininks-Oseretsky (Bruininks, 2000) motorinių igūdžių testus. Nustatyta, kad rengiant vaikus mokyklai sistemingai ir tikslingai atliekami įvairūs pirštų, riešo ir visos rankos judesių lavinimo pratimai skatina pozityvią rankų koordinacijos kokybinių ir kiekybinių rodiklių kaitą.

Akiu ir rankos koordinacija pasireiškia integruojant vizualiają informaciją ir ranku judesius. Kamuoliuko metymo i grindis ir gaudymo, metimo i taikini judesiai yra tik tada koordinuoti ir tikslūs, kai tinkamai integruojama vizualinè ir motorinè veikla (Gallahue, Ozmun, 2000). Siekimo ir griebimo judesiai priklauso nuo objekto dydžio. Rankos tiesimo ir griebimo judesiu koordinacija rodo laika, reikalingą pagriebti (pagauti) mažesnius daiktus. Griebiant mažesnius daiktus, pirštai tiesiami greičiau (Marteniuk et al., 1990). Gaudyti teniso kamuoliuką penkiamečiams vaikams buvo neiprasta. Pedagoginiai stebejjimai rodo, kad jiems sunkiai sekèsi suvokti, kokia jèga reikia mesti kamuoliuką i grindis, kad jis, atsimu- šęs i jas, atšoktų iki liemens aukščio (neatšoktų per aukštai ar per žemai). Vaikams ne visada pasisekdavo mesti kamuoliuką i grindis tiesia trajektorija, todè jis kartais atsimušdavo i pėdas ir nuriedèdavo arba atšokdavo ne tiesiai aukštyn, dèl to nebepavykdavo jo sugauti. Kamuoliuko gaudymo rezultatai gaudant abiem rankom geresni nei viena dèl to, kad gaudant abiem delnais gaudymo plotas yra didesnis. Kita vertus, penkerių metų vaikai neturi kamuoliuko gaudymo viena ranka patirties, nes paprastai žaidžia su dideliais kamuoliais. Vaikai taip pat dažnai nesugauna kamuoliuko net jam prisilietus prie delno dèl to, kad nespeja sureaguoti ir sulenkti pirštų. Lygindami abieju grupių penkeriu metų (pirmo tyrimo) mergaičių ir berniuku kamuoliuko metimo i grindis ir gaudymo abiem bei dominuojančia ranka užduočių rezultatų vidurkius pastebime, kad jie labai panašūs (žr. lent.).

Pagauti iš trijų metrų atstumo metamą kamuoliuką penkiamečiams vaikams sekèsi dar blogiau nei atšokusi nuo grindų, o abiem rankom - geriau nei viena. Vaikams sudètingiau nei suaugusiesiems įvertinti artėjančio kamuoliuko greiti, atstumą ir skriejimo trajektoriją. Tai suprato ir patys vaikai. Testavimo metu paaiškinus ir parodžius užduoti jie dažnai sakydavo, kad pagauti negebès, ypač viena ranka. Tekdavo raminti juos ir sakyti, kad svarbu artejjanti kamuoliuką idemiai sekti akimis ir stengtis pagauti. Mūsų tyrimo duomenys sutampa su D. Sinclair (1985) tyrimais ir teiginiu, kad 5 metu amžiaus vaiku gebejjimas gaudyti kamuoli yra išlavintas blogiau nei kiti pagrindiniai judesiai. Sèkmingam kamuolio gaudymui reikia geros akių ir rankų judesių koordinacijos, kuri šiuo amžiaus tarpsniu dar nèra tinkamai išlavinta.

Metimas i taikini yra sudètingas judesys. Jo technikos vaikai išmoksta sunkiau nei kitų pagrindiniu judesių. Metant į taikinị reikia nustatyti atstumą iki taikinio, ivertinti skriejimo trajektoriją, tiksliai atlikti judesi ir atitinkamai diferencijuoti kamuoliuko metimo jègą (Adaškevičienè, 1993). Penkerių metu vaikai iš penkiu bandymu i taikini pataikè tik vidutiniškai daugiau nei viena karta.

Judesių koordinacija yra gebejjimas integruoti skirtingas raumenu grupes ir jutimo sistemas, sukuriant veiksmingus judesių derinius. Kuo sudètingesnè motorinè užduotis, tuo geresnès koordinacijos reikia norint sèkmingai atlikti judesius (Barrow, McGee, 1978). Koordinuoti judesiai leidžia vaikui greitai ir tiksliai atlikti specifines 
judesių serijas. Judesiai turi būti sinchroniški, ritmiški ir atitikti reikiamą judesių seką (Gallague, Ozmun, 2000). Atliekant sudètingos koordinacijos judesius, labai svarbi rega. Tačiau BruininksOseretsky testuose ranku koordinacijai tirti yra dvi užduotys, kurios atliekamos užsimerkus. Jos iš dalies leidžia vertinti vaikų neuromotorini brendimą. Mūsų stebejjimai rodo, kad vaikams atlikti užduotis užmerktomis akimis buvo labai neịprasta. Pirmo tyrimo metu užmerkus akis liesti nosi rodomuju pirštų galais taisyklinga judesiu seka gebejjo ne visi. Kai kurie vaikai labai sulètindavo rankos judesi prieš pat paliesdami nosi, per ilgai ieškodavo jos galiuko, todèl trikdydavo ritmą. Vienos rankos pirštu palietus nosi, pamirštama ranką ištiesti per alkūnę ir iš karto lenkti kitą ranką buvo dažniausia penkiamečiu vaiku klaida. Nors atliekant užduotị testuotojas klaidas taisé žodžiu, dalis vaikų vis tiek neįstengdavo suprasti ir greitai ištaisyti klaidos. Kai kurie vaikai suprasdavo savo klaidą, tačiau nespedavo atlikti nenutrūkstamų taisyklingų rankų judesių sekų (per 90 sekundžių keturis kartus paliesti nosi), nes suklydus taisyklingi judesiai pradedami skaičiuoti iš naujo.

Nykščiu atlikdami iš eiles pirmyn ir atgal visu pirštų galų lietimo užduotị užmerktomis akimis, vaikai dažniausiai suklysdavo dèl to, kad per ilgai laikydavo suglaustus pirštų galus, tartum nebūtų tikri, ar iš tiesų juos paliete. Kartais paliesdavo tą pati piršto galą du kartus ar praleisdavo. Beveik nepasitaikè vaikų, kurie nykščiu paliestų du pirštus vienu metu. Būdavo ir tokiu, kurie praradę orientaciją ar kantrybę atsimerkdavo, nors prieš užduotị būdavo ispèti, kad atsimerkti galima tik atlikus užduotį.

Paskutinè užduotis - nykščiu ir rodomuju pirštų sukinejjimas (atmerktomis akimis) erdvinès koordinacijos požiūriu buvo ypač sudètingos judesiu sekos, reikalaujančios didelio susikaupimo, įdėmios pirštų ir riešų judesių kontrolès akimis. Pirmo tyrimo metu šią užduoti (skirtingose grupèse) sėkmingai atliko nuo 48,00 iki $63,64 \%$ vaikų. Remiantis pedagoginiais stebejjimais galima teigti, kad pagrindinè priežastis, dẻl ko tiek penkerių, tiek šešerių metu vaikams ši užduotis būdavo neịskaityta — negebejjimas suvokti, kad riešus reikia sukti ị priešingas puses.

Koordinacija - labai sudètinga psichomotorinė ypatybė. Koordinaciniai gebejjimai, pasak V. I. Liacho (Лях, 2000), išsiskiria tokiais pagrindiniais požymiais: taisyklingumu, greitumu, racionalumu ir sumanumu. Visi šie požymiai dar turi kiekybi- niu ir kokybiniu ypatumų. Gebejjimų vertinimo kriterijų kokybiniai ypatumai yra tolygumas, operatyvumas, tikslingumas, iniciatyvumas, kiekybiniai - tikslumas, greitumas, ekonomiškumas ir pastovumas. Pirmas testavimas ir pedagoginis stebejjimas leidžia teigti, kad dauguma penkiamečiu vaiku jau geba atlikti gana sudètingas, neiprastas rankų koordinacijos užduotis, nors judesiai dar ne visada tikslūs, ekonomiški ir operatyvūs, judesiu sekos laiko atžvilgiu dažnai netolygios. Neretai rankų koordinacijos užduočių atlikimo sẻkmė priklauso ne tik nuo judejimo patirties, bet ir nuo gebejjimo sukaupti, išlaikyti dẻmesi, pasitikèjimo savo jègomis.

Šeštais ir septintais gyvenimo metais visu tirtų vaikų rankų koordinacija gerejjo, tačiau E grupès vaiku kur kas sparčiau. Eksperimento pabaigoje E grupès mergaičiu ranku koordinacijos vidutiniai rodikliai buvo statistiškai patikimai geresni atliekant septynias, berniuku — šešias užduotis ( $\mathrm{p}<0,05-0,001)$, lyginat su $\mathrm{K}$ grupe. Pedagoginiai stebejjimai rodo, kad antro ir trečio tyrimo metu E grupès vaikai gebejjo gana tiksliai ivertinti kamuoliuko skriejimo trajektoriją ir atstumą, isstengè daug greičiau įsidemèti ir pakartoti sudètingas ranku ir pirštu judesių sekas, labiau koncentruodavo dèmesi, atidžiau klausè aiškinimų nei $\mathrm{K}$ grupès vaikai. Jau antro tyrimo metu pastebejome, kad kamuoliukui prisilietus prie delno E grupès vaikai dažniau spèdavo laiku sulenkti pirštus. Jie užduoties atlikimo metu rečiau klydo, greičiau taisè nurodytas klaidas. Buvo šešiamečiu (tiek mergaičių, tiek berniukų), kurie vieną ar kelias užduotis atliko blogiau nei per pirmą tyrimą (penkerių metu). Ypač tai buvo akivaizdu $\mathrm{K}$ grupès berniukams atliekant nykščių ir pirštų sukinejjimo užduotị. Didelè rankų koordinacijos individualių rezultatų sklaida. Tai sutampa su ikimokyklinio amžiaus vaikų koordinaciją tyrusių mokslininkų teiginiais ir gautais rezultatais (Durandt, 1985; Михайлова, 1990; Лагутин, Амарян, 2002). Ivairių pasaulio šalių mokslininkai, tyrinejję ir analizavę ikimokyklinio amžiaus vaiku motorikos lavejjimą, yra pastebèję didelius individualių rezultatų skirtumus. Priešmokyklinio amžiaus tarpsniu vaikai mokosi labai daug naujų judesių, todèl vieną kartą užduoti gali atlikti geriau, kitą — blogiau.

Ugdomojo eksperimento rezultatai rodo, kad kryptingai ir tikslingai organizuoti rankų, riešo ir pirštų lavinimo žaidimu pratimai, žaidimai su kamuoliu gerina ranku judesių koordinacijos kokybinius ir kiekybinius rodiklius. Mūsu atliktas 
eksperimentas patvirtina mokslininkų (Durandt, 1985; Михайлова, 1990; Лагутин, Амаръян, 2002; Dankert et al., 2003; Sugden, Chambers, 2003), tyrusiu penkeriu—septyneriu ir vyresnio amžiaus sveikus bei koordinacijos sutrikimų turinčius vaikus, ir jų tyrimų rezultatais pagrịstus teiginius, kad fizinio ugdymo programose tikslinga naudoti gana sudetingas koordinacijos lavinimo užduotis, kuriose būtina sąmoninga judesių integracija ir suvokimo kontrolè.

\section{IŠVADOS}

1. Dauguma penkiamečių vaikų geba atlikti gana sudètingus koordinaciniu požiūriu rankų judesius. Berniukų ir mergaičiu ịvairių rankos koordinacijos užduočių rezultatai labai panašūs. Nustatyti gana ryškūs individualūs skirtumai. Yra vaikų, kurie stokoja akių ir rankos judesių kontrolès, lytėjimo ir kinestezinio jutimo išlavinimo.

2. Šeštais ir septintais gyvenimo metais visų tirtų vaiku rankų koordinacijos rezultatai gerèjo, tačiau E grupés mergaičiu ir berniukų gerejo labiau ir eksperimento pabaigoje, lyginat su $\mathrm{K}$ grupe, E grupès mergaičiu buvo statistiškai patikimai geresni septynių užduočiu, E berniuku - šešių.

3. Naudota rankų koordinacijos lavinimo programa akivaizdžiai padeda optimizuoti vaikų fizini brandinimą mokyklai. Pakitus rankų judesių kryptingumui ir tikslingumui keičiasi ranku judesiu koordinacijos kokybiniai ir kiekybiniai ypatumai: judesiai atliekami laiku, darosi tikslingesni, racionalesni, ekonomiškesni, tikslesni ir stabilesni. Gerèja regos, lytèjimo, tinkamo raumenų itempimo ir atpalaidavimo jutimas, atliekamu judesių suvokimas.

\section{LITERATŪRA}

Adaškevičienè, E. (1993). Lietuvos ikimokyklinuku fizinis ugdymas. Kaunas: Šviesa.

Barrow, H. M., McGee, R. (1978). A Practical Approach to Measurement in Physical Education. Philadelphia: Lea \& Febiger.

Bruininks, R. H. (2000). Bruininks-Oseretsky Test of Motor Proficiency: Examiner's Manual. Circle Pines, Minnesota: American Guidance Service.

Bruininks, R. H., Sullivan, L., Short, N. J. (1974). Visualmotor Abilities of Disabled and Nondisabled Children: Paper Presented at the $52^{\text {nd }}$ Annual International Convention of the Council for Exceptional Children. New York.

Dankert, H., Davies, P., Gavin, W. (2003). Occupational therapy effects on visual-motor skills in preschool children. The American Journal of Occupation Therapy. 57, $542-549$.

Durandt, R. (1985). Ball catching proficiency among 4, 6 and 8-year-old girls. In J. Clark, J. Humphrey (Eds.), Motor Development: Current Selected Research (pp. 35-44). Princeton, NJ: Princeton Book Co.

Gallahue, D. L., Ozmun, J. C. (2000). Understanding Motor Development. Champaign, IL: Human Kinetics.

Grinienè, E., Lindišienė, D., Maračinskienė, E., Vaitkevičius, J. (1990). Mokymosi įtaka vaiko ir paauglio organizmui. Kaunas: Šviesa.

Inui, N., Katsura, Y. (2002). Development of force control and timing in a finger-tapping sequence with an attenuated-force tap. Motor Control, 6, 333-346.

Kephard, N. C. (1971). The Slow Learning in the Classroom. Columbus, Ohio: Merrill.

Kuhtz-Buschbeck, J. P., Stolze, H., Jöhnk, K., BoczekFurcke, A., Illert, M. (1998). Development of prehension movements in children: A kinematics study. Experimental Brain Research, 122 (4), 424-432.

Marteniuk, R. G., Leavitt, J. L., McKenzie, C. L., Athenes, S. (1990). Functional relationships between grasp and transport components in a prehension task. Human Movement Science, 9, 149-176.

Sinclair, D. (1985). Human Growth after Birth. $4^{\text {th }} \mathrm{ed}$. London: Oxford University Press.

Søvik, N., Maeland, A. F. (1987). Children with motor problems on writing performance of dysgraphic children. Scandinavian Journal of Educational Research, 28, $129-147$.

Strazdienè, N. (2001). Darbo mokejimo ir igūužiu ugdymo sistemine plètra pradinejje mokykloje: soc. m. daktaro disertacija. Klaipèda.

Sugden, D. Chambers, M. (2003). Intervention in children with developmental coordination disorder: The role of parents and teachers. British Journal of Educational Psychology, 73, 545-561.

Лагутин, А. Б., Амаръян, Р. И. (2002). О переемственности физического воспитания детей дошкольного и младшего школьного возраста. Физическая культура в школе, 4, 12-15.

Лях, В. И. (2000). Координационные способности школьников. Физическая культура в школе, 4, 6-13.

Михайлова, С. (1990). Развитие координационных движений у детей 6-7 лет, как основа повышения их физической подготовленности: дис. канд. пед. наук. Ленинград.

Тулва, Т. А. (1976). Педагогические условия повышения работоспособности младших школьников: дис. канд. пед. наук. Ленинград. 


\title{
TRAINING INFLUENCE ON THE CHANGES OF 5-7 YEAR OLD CHILDREN'S UPPER-LIMB COORDINATION RESULTS
}

\author{
Zina Birontienè \\ Klaipèda University, Klaipèda, Lithuania
}

\begin{abstract}
The aim of the study was to examine the changes of $5-7$ year old children's upper-limbs coordination results stimulating their physical maturing for school.

The following research methods were applied: educational experiment, testing, pedagogical observation, and statistical analysis. The educational experiment lasted for 20 months. 120 children from Klaipeda kindergartens participated in the experiment. The children from the experimental (E) group were educated according to our created physical preparation for school program. The basis of upper-limbs coordination training consisted of finger, hand, and arm exercises and ball games. The control (C) group used the program "Vèrinèlis", certified by the Ministry of Education and Science of the Republic of Lithuanian. Three control studies were conducted. The children had to perform five tasks with a tennis ball and three finger touching exercises which assess coordination of visual tracking with movements of the arms and hands, as well as precise movements of the arm, hands and fingers.

During the first research, the obtained results of the upper-limbs coordination from Groups $\mathrm{E}$ and $\mathrm{C}$ were very similar. During the eight months of purposeful training of upper-limbs coordination it was estimated that the girls in Group E significantly statistically improved $(p<0.01-0.001)$ in seven tasks, and the boys in Group E - in eight tasks ( $p<0.01-0.001)$. However, the girls in Group C improved in one task $(\mathrm{p}<0.01)$, the boys in Group $\mathrm{C}$ improved in one task $(\mathrm{p}<0.05)$ and were worse in one task $(p<0.05)$. Group E girls and boys mean results of the second research were statistically significantly better in seven tasks $(\mathrm{p}<0.01-0.001)$ comparing with Group $\mathrm{C}$ girls and boys' results. During the rest twelve months the upper-limbs coordination of the children from all the groups improved, but Group E girls' mean results statistically significantly improved in five tasks $(\mathrm{p}<0.01-0.001)$, and Group E boys' - in four tasks $(\mathrm{p}<0.05-0.001)$. Group $\mathrm{C}$ girls improved in four tasks $(\mathrm{p}<0.05)$, and Group $\mathrm{C}$ boys - in five tasks $(\mathrm{p}<0.05-0.001)$. Group E children were better at catching a ball, coordinating finger tip touching tasks with open or closed eyes, and were more precise in throwing something into the target. In the third research Group E girls were statistically significantly better in seven tasks $(\mathrm{p}<0.01-0.001)$, and Group E boys - in six tasks $(p<0.01-0.001)$ comparing with Group C. All the studies showed great individual upper-limbs coordination differentiation.

Our research results are similar to those of the scientists (Durandt, 1985; Михайлова, 1990; Лагутин, Амаръян, 2002; Dankert et al., 2003; Sugden, Chambers, 2003), who researched healthy young children and children with coordination disorders and confirm that in training programs it is purposeful to use complicated coordination tasks which demand conscious integration of senses and perception control. The results of the educational experiment showed that systematic and purposeful hand, wrist, and finger training activities and games with a ball improve quantitatived and qualitative parameters of hand coordination
\end{abstract}

Keywords: upper-limbs coordination, Bruihninks-Oseretsky tests for motor proficiency, 5-7 year old children's physical preparation for school.

Gauta 2009 m. gegužès 26 d.

Received on May 26, 2009

Priimta $2010 \mathrm{~m}$. vasario $4 \mathrm{~d}$.

Accepted on February 4, 2010
Zina Birontienè

Klaipèdos universitetas

(Klaipèda University)

S. Nèries g. 5, LT-92227 Klaipèda

Lietuva (Lithuania)

Tel +37046398617

E-mail zina.birontiene@gmail.com 